12.

\title{
MEĐUNARODNI SVEUČILIŠNI \\ CENTAR U KULI STOJANA \\ JANKOVIĆA, ISLAM GRČKI: PROŠLOST, \\ SADAŠNJOST I BUDUĆNOST OBNOVE \\ I PRENAMJENE SJEVERNOG KRILA \\ SKLOPA KULE
}

\section{Alan Braun}

UDK: 727:728.81(497.5 Islam Grčki)

Sažetak: Tijekom proteklog desetljeća veliki je trud uložen u obnovu središnjeg, stambenog dijela Kule Stojana Jankovića u Islamu Grčkom, ali i u pokušaje održivog korištenja cijelog sklopa. Ovo pojedinačno zaštićeno kulturno dobro, bez sumnje predstavlja turistički potencijal, ali cjelogodišnju aktivnost Kuli može donijeti samo trajnija namjena, poput one znanstveno-nastavne. Studija idejnog rješenja, koju je izradio Zavod za graditeljsko nasljeđe Arhitektonskog fakulteta Sveučilišta u Zagrebu, predviđa obnovu i prenamjenu, sada posve zapuštenog, gospodarskog krila koje formira sjeverni obod sklopa Kule za potrebe Međunarodnog sveučilišnog centra. Ovakva bi namjena omogućila korištenje sklopa tijekom većeg dijela godine. Studenti i mladi stručnjaci, njihovi profesori i mentori, mogu donijeti novu živost ovom povijesnom sklopu bogate, ali i bremenite prošlosti.

Ključne riječi: idejno rješenje, Islam Grčki, Kula Stojana Jankovića, Međunarodni sveučilišni centar, sjeverno krilo

Ne obnavljamo spomenik jer ga smatramo lijepim, već jer je dio našeg nacionalnog postojanja. Zaštititi spomenik ne znači tražiti užitak, već iskazati poštovanje. Iako su sudovi estetike i povijesti umjetnosti promjenjivi, ovdje nalazimo stalne, karakteristične vrijednosti.

Georg Gottfried Dehio, 1905.

(

dnos prema kulturnim dobrima, bez ikakve sumnje, pokazuje nivo društvenog razvoja. I ne samo danas. Već od samih začetaka sustavne skrbi o kulturnim dobrima, početkom 19. stoljeća, o potrebi da za buduće generacije sačuvamo ono najvrednije u graditeljstvu i umjetnosti, pisali su Hugo, Goethe ili Kukuljević. No, bez obzira na podignute glasove nacionalne intelektualne elite, zaštita kulturnih dobara je, kroz sve vrijeme razvoja kao samostalne discipline, relativno blisko povezana is politikom. 


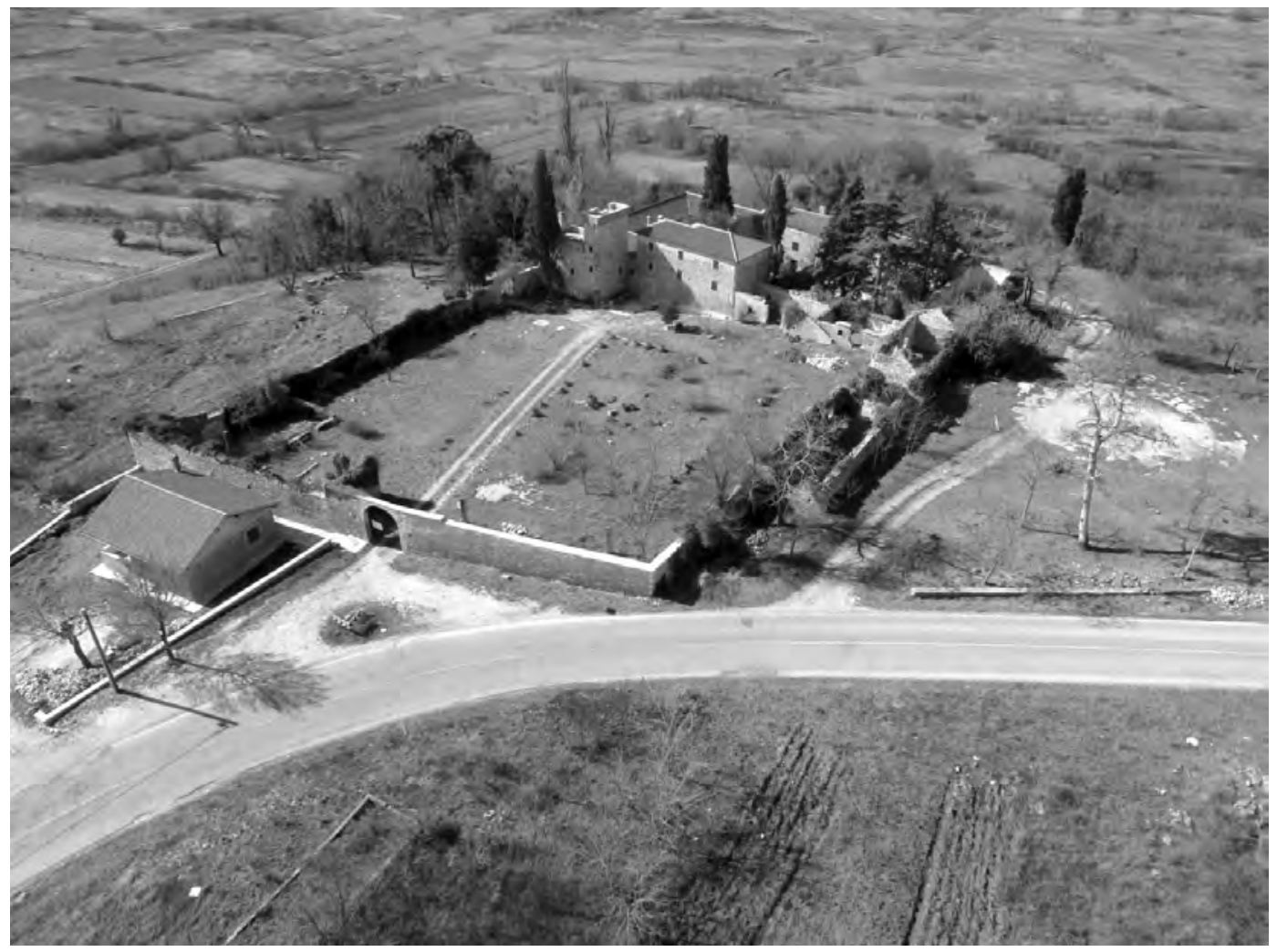

Slika 1. Kula Stojana Jankovića - pogled iz zraka, 2012.

Prošlo nas stoljeće uči da nagla razaranja kulturnih dobara, potresi, poplave ili ratovi, uvijek iznova potiču rasprave kako obnavljati graditeljsku baštinu koja je u njima stradala. Tragična europska iskustva svjetskih ratova bitno su utjecala, kako na odnos prema baštini, tako i na metode njene obnove. Poljski ili njemački gradovi faksimilski su, u relativno kratkom vremenu, rekonstruirani tako reći iz pepela. Bilo je to pitanje od nacionalnog značenja. No, upravo je takav odnos prema obnovi baštine nakon Drugog svjetskog rata na neki način iznjedrio surovu taktiku suvremenih svjetskih sukoba: uništavanje kulturnih dobara kao dio (ne)službene politike. Ako uništimo nasljeđe, uklonit ćemo i svaki dokaz trajanja.

Povijest Kule Jankovića, fortifikacijsko-stambenog sklopa izgrađenog u Islamu Grčkom, na granici Mletačke Republike i Osmanskog Carstva, snažno je označena upravo sukobima i granicom. Sazdana da brani granicu koju ondašnja Europa smatra granicom svega civiliziranog, svoje je breme zadržala do današnjeg dana. Stradala je i u Domovinskom ratu, ali ovoga puta ne zbog svojih strateških karakteristika, već upravo kao vrijedno kulturno dobro.

Danas, svjesni važnosti kulturnih dobara kao biljega nacionalnog identiteta, u njedrima Europe koja briše pojam granice, nalazimo se pred izazovnim zadatkom obnove ovog kulturnog dobra. Suvremena nas disciplina zaštite graditeljskog nasljeđa uči, da je pravilno odabrana buduća namjena povijesne građevine, ključan faktor njene održivosti i trajanja. A ovaj bogati sklop, obiteljsko nasljeđe, ima budućnost samo ako "izađe" iz svojih visokih zidova i postane žarišna točka relativno uspavanog kraja u zadarskom zaleđu. Sve što je obitelj godinama brižno čuvala i spašavala, treba pokazati dobronamjernim gostima. 
Problematika obnove ovog kulturnog dobra vrlo je složena. Ne samo da treba iznaći optimalne namjene za brojne prostore ovog povijesnog sklopa, već treba pažljivo razmotriti i artikuliranje velikih vanjskih prostora, definiranih kako zgradama sklopa, tako i visokim ogradnim kamenim zidom. Tek kada se projektom odredi budući način korištenja ovih prostora, stvara se okvir za zasebni pristup svakom strukturalnom elementu Kule Jankovića. U proteklih desetak godina, veliki je posao na obnovi stambenog dijela Kule napravljen pod vodstvom stručnjaka iz Uprave za zaštitu kulturne baštine, Konzervatorskog odjela u Zadru što je stvorilo pretpostavku za ponovno otvaranje Kule Jankovića zainteresiranoj javnosti.

Pored obitelji, vlasnika kulturnog dobra, bez koje nema svakodnevne brige, ali ni svakodnevnog života u Kuli, dvije su značajne skupine koje mogu ovu povijesnu strukturu oživjeti tijekom većeg dijela godine. Prvu predstavljaju turisti, koji su pogotovo tijekom ljetnih mjeseci pozvani posjetiti Kulu i zavičajnu zbirku, iako moramo biti svjesni da je njihovo zadržavanje relativno kratkotrajno. Stoga je valjalo domisliti kako prostore Kule ispuniti dugotrajnijim posjetiteljima i to tijekom većeg dijela godine. Temelj odluke da se u sjevernom, gospodarskom krilu sklopa Kule Jankovića, organizira Međunarodni sveučilišni centar, treba tražiti u uspješno organiziranim akademskim događanjima u Kuli kao što su "Dani Vladana Desnice" ili pomalo "robinzonske" međunarodne ljetne škole koje su se zadnjih godina ovdje održavale. U vremenima kada cjeloživotno obrazovanje postaje preduvjet akademskog uspjeha, studenti ili polaznici poslijediplomskih studija mogli bi ovim prostorima donijeti novu dinamiku.

Međunarodni sveučilišni centar, kao jedna od sastavnica ove nove pulsirajuće zajednice, smješten je u sjevernom, gospodarskom, pomoćnom krilu Kule. Krilo je izduljena kamena građevina naslonjena na vanjski perimetralni zid sklopa. Sastoji se od nekoliko zasebnih cjelina, orijentiranih prema unutrašnjem dvorištu i do danas nije obnavljano nakon teškog oštećivanja u devedesetim godinama prošlog stoljeća. Budući da krovovi nisu sačuvani, kiša ispire vezni materijal kamenog ziđa, a raslinje svake godine uzrokuje nove štete. Kako uskoro od sjevernog krila ne bi ostala samo hrpa kamenja koja dokazuje da su ponekad priroda i ljudska nebriga razorniji od požara ili rata, potrebno je hitno stvoriti uvjete za obnovu ovog dijela graditeljskog sklopa u Islamu Grčkom. Moramo biti svjesni da su prostori sjevernog krila Kule relativno skromni, kako u oblikovanju (radi se o utilitarnoj povijesnoj arhitekturi), tako i u veličini jer govorimo o petstotinjak kvadrata korisne površine. No, na to ne treba gledati kao na nedostatak, već kao optimalnu prostornost s obzirom na značajna sredstva koja treba uložiti u obnovu ovog devastiranog kamenog volumena, a istovremeno kao i na projektantski izazov da se u život Međunarodnog sveučilišnog centra uključe i vanjski prostori, gotovo jednako važni tvorbeni element ovog povijesnog sklopa. Jednostavne kamene volumene potrebno je rekonstruirati u svoj snazi njihove rudimentarne jednostavnosti, a veliku masu dvostrešnog krova pokriti tradicionalnim materijalom kupe kanalice i rastvoriti nizovima krovnih prozora kojima bi se osvijetlilo sadržaje Međunarodnog sveučilišnog centra - prostore škole, dormitorija i prehrane, a da se pri tome ne naruši izvorna ljepota kamenog ziđa sjevernog krila Kule.

Kao i svaki drugi projekt iz domene povijesne arhitekture, tako je i obnova i prenamjena sjevernog krila Kule Jankovića, na neki način jedinstvena i nije lako pronaći usporedne primjere. Naravno tema sveučilišnog centra u povijesnoj zgradi nije novost. Zavod za graditeljsko nasljeđe Arhitektonskog fakulteta Sveučilišta u Zagrebu autor je projektne dokumentacije za Centar Sveučilišta u Rijeci u patricijskoj gradskoj kući Moise u Cresu. 


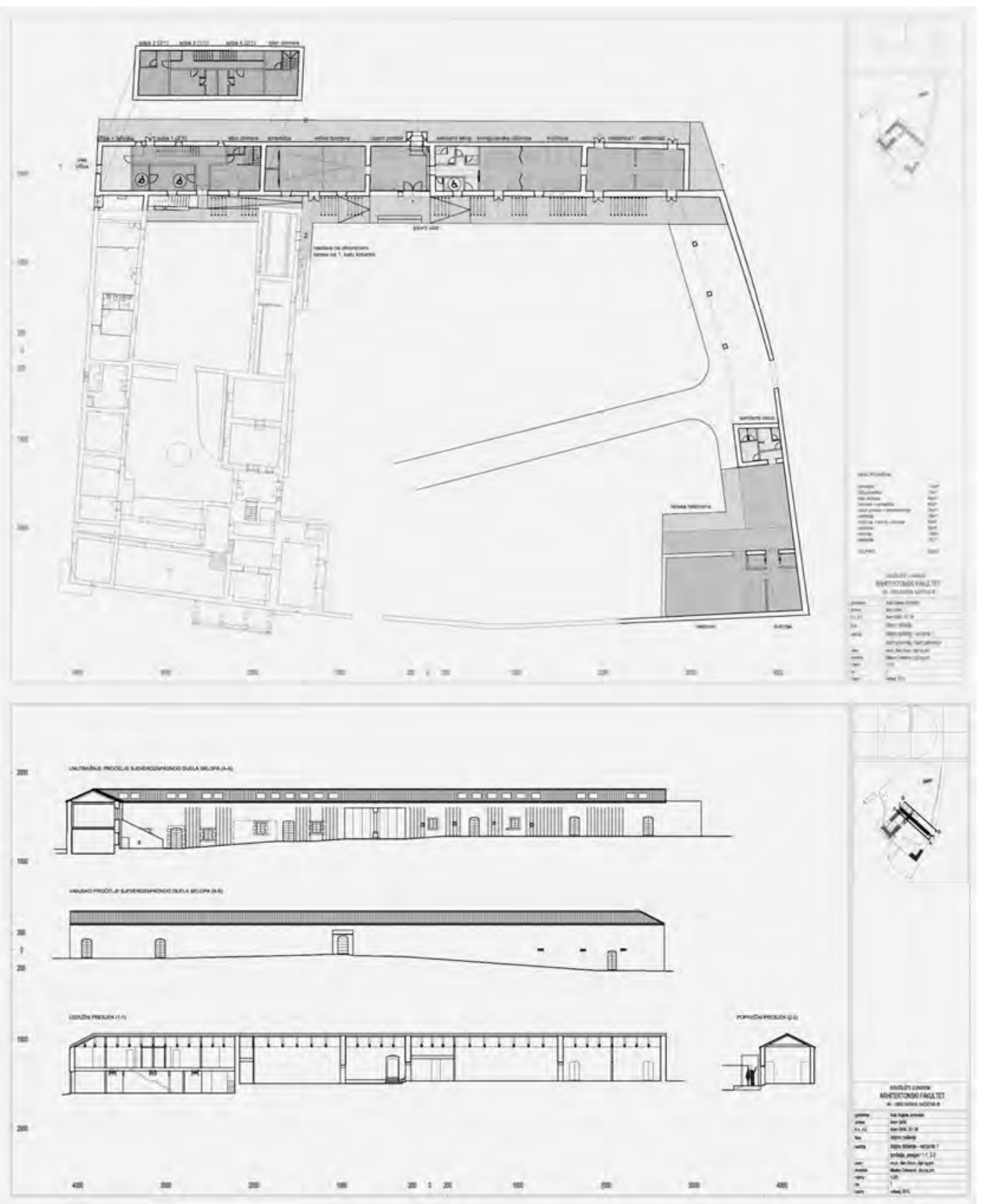

Slika 2. Međunarodni sveučilišni centar u Kuli Stojana Jankovića, Islam Grčki, Hrvatska. Studija idejnog rješenja, 2013.

No, teško je uspoređivati atmosferu srednjovjekovne fortifikacijsko/gospodarske arhitekture s odmjerenošću renesansne patricijske kuće, bez obzira što će oba prostora, nadamo se u skoroj budućnosti, imati istu namjenu.

Novu kvalitetu ovog izvorno sekundarnog prostora treba iznaći u dinamičnom spajanju unutarnjeg i vanjskog prostora - svaki od predviđenih sadržaja dobiva svojevrsnu 

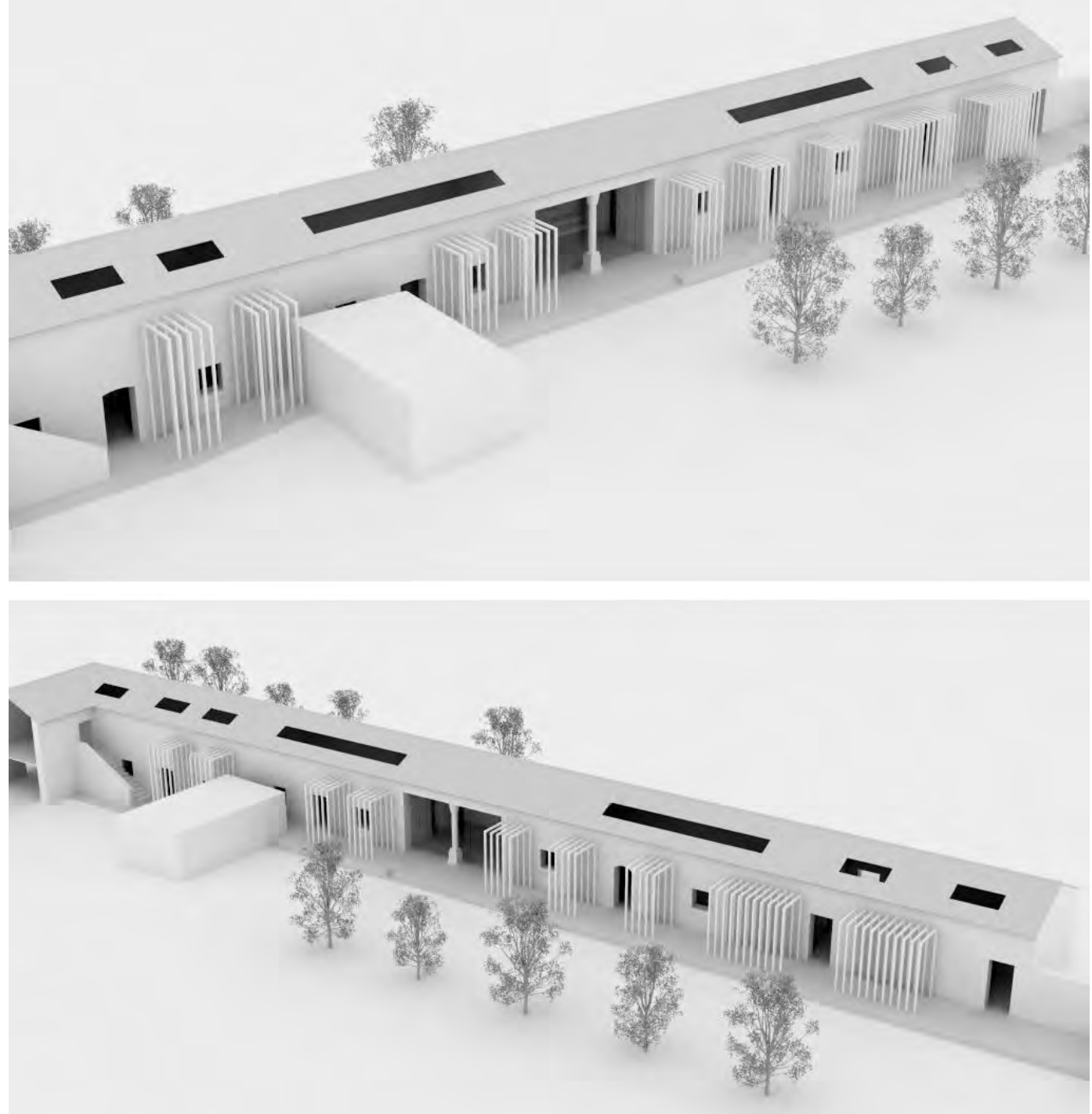

Slika 3. Međunarodni sveučilišni centar u Kuli Stojana Jankovića, Islam Grčki, Hrvatska. Trodimenzionalni model studije idejnog rješenja, 2013.

"terasu", a sve one zajedno čine platformu - palubu s koje se prilazi različitim jedinicama i sadržajima sveučilišnog centra - samoj školi, dormitoriju i prostorima ugostiteljstva. Novu kvalitetu treba iznaći u izazovu spajanja povijesnog prostora i suvremene namjene - kada uđemo u kamena zdanja sjevernog krila Kule dočekuju nas edukacijski i ostali prostori Međunarodnog sveučilišnog centra koji u svemu odgovara današnjem trenutku. Novu kvalitetu treba tražiti u svakodnevnoj aktivnosti u ovom dugovremena utihnulom prostoru, iza visokih povijesnih zidova sklopa; treba se okrenuti budućnosti. Takvo kvalitetnije nasljeđe za buduće generacije zasigurno mogu garantirati studenti i mladi stručnjaci, njihovi profesori i mentori koji će dati novi sloj ovom povijesnom sklopu bogate, ali i bremenite prošlosti. 


\section{$\cos$}

\section{Literatura}

FEILden, Bernard. 2003. Conservation of Historic Buildings. Oxford: Architectural Press.

Jokilehto, Jukka. 2006. A History of Architectural Conservation. Oxford: Butterworth-Heinemann.

Šrikić, Marko. 1996. Historical and Philosophical Issues in the Conservation of Cultural Heritage. Price, N.S., Talley, M.K., Melucco Vaccaro, A., ed. Los Angeles: The Getty Conservation Institute. Špıкıć, Marko. 2001. Konzerviranje i restauriranje, Kolo 1, Zagreb: Matica hrvatska.

Šsıкіć, Marko, ur. 2006. Anatomija povijesnog spomenika. Zagreb: Institut za povijest umjetnosti. ŠsıкіĆ, Marko. 2009. Konzerviranje europskih spomenika od 1800. do 1850. Zagreb: Leykam.

\section{Izvori ilustracija}

Slika 1. Geodetski fakultet Zagreb

Slike 2. i 3. Alan Braun, Mladen Cvitanović: Studija idejnog rješenja Međunarodnog sveučilišnog centra u Kuli Stojana Jankovića, Arhitektonski fakultet, Zavod za graditeljsko nasljeđe, Zagreb, 2013.

\section{cos \\ Komentar \\ Uroš Desnica}

Kula Stojana Jankovića spomenik je (zaštićeno kulturno dobro) izrazito višeslojnih i raznovrsnih kvaliteta: kulturno-povijesnih (burna povijest na tromeđi, niz izuzetnih ličnost "od Stojana Jankovića do Vladana Desnice" te višestoljetni arhivi), kulturno-umjetničkih (vrlo vrijedne i raznovrsne zbirke), ambijentalnih te parkovnih vrijednosti (park na 4 ha, $s$ arboretumom, romaničkom crkvom, izvorima vode i velikom, višenamjenskom peškijerom - i sam je klasificiran kao "spomenik parkovne arhitekture").

Kombinacija tih raznorodnih vrijednosti čini kompleks atraktivnim za brojne i različite načine korištenja. Da bi se ti potencijali iskoristili bitno je dovršiti (već dobrano poodmaklu) obnovu Kule do kraja, uspostaviti u njoj Muzealno-informativni centar u povijesnom dijelu i Medunarodni sveučilišni centar u ranijem "ekonomskom" dijelu kompleksa. Koristeći sinergiju tih dvaju tipa sadržaja, Kula ima uvjete da postane kompleks s cjelogodišnjim funkcioniranjem, pokretač održivog razvoja Ravnih kotara te izvorište razvojnih, kulturnih, muzeoloških, edukativnih i turističkih projekata, na dobrobit čitave regije, a čime bi se ujedno osiguralo i njenu vlastitu samoodrživost.

Popis svih tekućih i završenih projekata te popis svih, vrlo raznovrsnih revitalizacijskih aktivnosti u Kuli Stojana Jankovića i oko nje impresivan je ${ }^{1}$. Analiza svih dobivenih međunarodnih i domaćih projekata i financiranih revitalizacijskih aktivnosti pokazuje:

1 Popisi se mogu pronaći na www.kulajankovica.hr. 
a) raznovrsnost tema odobrenih projekata (Kula kao pokretač razvoja regije, Kula kao paradigma pomirbe i socijalnog sklada, Kula kao turistički zanimljivo kulturno dobro, Kula kao mjesto događanja manifestacija, skupova, ljetnih kampova, edukacije mladih, mjesto kulturnih, razvojnih i turističkih sadržaja itd.;

b) velika raznolikost investitora: Ministarstvo kulture RH, Ministarstvo turizma RH, Vlada RH, SNV, Obrazovne institucije (UNIZG i FFZG), EU fondovi (i to različite agencije), američka fundacija Tourism Cares i drugi.

Dosadašnja ukupna sredstva dobivena u posljednjem desetljeću za revitalizacijske aktivnosti u Kuli Jankovića i oko nje osjetno nadmašuju ukupna sredstva potrošena za obnovu Kule, od početka 2003. godine do danas.

Posebno je zanimljivo da su teme koje se bave ublažavanjem posljedica rata (smanjenje tenzija, socijalna stabilizacija) $s$ Kulom u fokusu pokazale izrazito velik potencijal za dobivanje sredstava iz EU fondova pa su tako $3 \mathrm{EU}$ projekta realizirana do sad. Uspješno razrješavanje tih problema očito Europska unija, iz vlastitih iskustava u više europskih zemalja, smatra bitnim uvjetom za socijalnu stabilnost i razvoj pa ih u regijama kao što je zadarsko zaleđe, sa svježim traumama ratnih sukoba, zapravo smatra neophodnim preduvjetom i za ekonomski oporavak i za opći napredak područja. Stoga Kula Jankovića, kao zajedničko pozitivno povijesno nasljeđe i Hrvata i Srba u regiji ima komparativnu prednost (i) za takve projekte.

\section{Komentar}

\section{Darko Babić}

Prilog koji slijedi donosi određeni broj sugestija i komentara uz održanu/e radionicu/e no istovremeno nadilazi ove aktivnosti i usmjeren je na dugoročniju razradbu kako koncepcije revitalizacije Kule Stojana Jankovića i razvitka Međunarodnog sveučilišnog centra u Kuli, ali istovremeno i aktivnosti Centra za komparativnohistorijske i interkulturne studije (osnovanog pri Filozofskom fakultetu Sveučilišta u Zagrebu 2012. godine) koji bi trebao biti pokretač i nositelj većine aktivnosti koje će se provoditi u Kuli Stojana Jankovića, posebice aktivnosti Međunarodnog sveučilišnog centra.

Kula Stojana Jankovića i obližnja crkva sv. Đurđa imaju pravni status zaštićenog kulturnog dobra. Prema vrsti spadaju u nepokretno kulturno dobro, a prema klasifikaciji u sakralno-profanu graditeljsku baštinu. Zgrade i dvorišta središnjeg dijela kompleksa Kule osobiti su sklop gospodarskih, fortifikacijskih i rezidencijalnih objekata ukupne površine približno $4300 \mathrm{~m}^{2}$. Sjeverni dio kompleksa, sukladno "Sporazumu o utemeljenu Međunarodnog sveučilišnog centra u kompleksu Kule Stojana Jankovića” između Sveučilišta u Zagrebu i vlasnika, namijenjen je uređenju u svrhu obavljanja raznovrsnih djelatnosti i programa Međunarodnog sveučilišnog centra (MSC), uključujući i smještaj za istraživače. Osim ovog već postignutog dogovora o sjevernoj fronti Kule, vlasnici su iskazali spremnost omogućavanja javnog korištenja i drugih dijelova kompleksa, sasvim konkretno velikog dijela povijesne 
jezgre Kule Jankovića (“Kule”, “Stare kuće”, zgrade sa "Salom” i “Ortulanice”, uz crkvu sv. Đurđa i arboretum) s izraženom željom da se iste uredi kao memorijalno-muzejski dio u kojem bi bili izloženi najvrjedniji dijelovi iz zbirki Kule Jankovića te stvori prostor koji bi omogućio pristup i studij bogatih arhivskih materijala, biblioteci te ostavštini Vladana Desnice, ali jednako tako i da dio navedenih prostora bude posvećen drugim, kompatibilnim, muzejsko-interpretacijskim sadržajima.

Osnovna je ideja korištenje Kule za dobrobit kraja i ljudi koji tamo obitavaju od strane različitih organizacija ili institucija kroz održivi razvoj koji pak uključuje i otvorenost javnosti za raznovrsne kulturne, edukativne, istraživačke, razvojne i slične projekte. Navedeno nudi mogućnosti oko organizacijskih potreba predviđenog budućeg muzeja i suradnje - moguće kao podružnice postojećih muzeja (ponajprije Zavičajnog muzeja Benkovac) ili kao mogući začetak/podružnica Muzeja Sveučilišta u Zagrebu. Iz svega proizlazi da aktivnosti Međunarodnog sveučilišnog centra koji nastaje u kompleksu Kule Stojana Jankovića pod vodstvom Centra za komparativnohistorijske i interkulturne studije i budućeg muzeja treba promatrati sinergijski te da i planiranje, a posebice buduće aktivnosti oba treba na taj način i razvijati. U ovom kontekstu svakako treba spomenuti da će (postepenim) razvijanjem sadržaja u Kuli, neovisno jesu li inicirani i realizirani od strane Međunarodnog sveučilišnog centra, budućeg planiranog muzeja ili kroz neki drugi modalitet, obogatiti ponudu gornjih Ravnih kotara i u turističkom smislu, odnosno u formiranju i kreiranju privlačne (turističke) destinacije za raznovrsne posjetitelje orijentirane prvenstveno prema kulturnoj i edukativnoj ponudi, no jednako tako i svih ostalih zainteresiranih.

\section{Predložene sugestije - razvoj Medunarodnog sveučilišnog centra i Muzeja}

Kako će očekivani osnovni nositelj budućih aktivnosti u Kuli biti Međunarodni sveučilišni centar logično je da uređenje potrebnih prostora za isti ima prioritet. Utilitarnost prostora (smještajni kapaciteti, multimedijska dvorana itd.) koji istovremeno poštuju osnovne konzervatorske zahtjeve pri tome su ključni.

U daljnjoj i nadasve bitnoj fazi razvoja, potrebno je urediti i muzejske prostore u Kuli koji će obogatiti i nadopunjavati aktivnost koje organizira MSC $s$ jedne strane, ali istovremeno biti i ključan element u definiranju Kule kao poželjne destinacije za turistički obilazak. Štoviše, a sukladno predloženoj muzeološkoj koncepciji, muzej u Kuli postao bi polazišna točka za stručna istraživanja i/ili rekreativno-turistički obilazak područja cijelih gornjih Ravnih kotara ovisno o preferencijama korisnika. Da bi se u tome uspjelo potrebno je osigurati redovite cjelogodišnje aktivnosti (skupove, seminare, izložbe, kulturna događanja itd.) koji će destinaciju učiniti privlačnom u sezoni, ali posebice i izvan redovite turističke sezone.

Mogući poželjni pravci promišljanja u smislu kvalitetnog razvoja MSC i budućeg muzeja u Kuli u tom smislu uključuju:

- povezivanje i zajednička organizacija aktivnosti sa sličim sveučilišnim centrima odnosno sveučilištima, ponajprije onih s Mediterana;

- povezivanje i zajednička organizacija aktivnosti budućeg muzeja u prepoznate, tematski slične međunarodne mreže muzeja (npr. International Network of Museums for Peace; Social Justice Alliance for Museums; International Coalition of Sites of Conscience itd.). 


\section{Predložene sugestije - razvoj Centra za komparativnohistorijske $i$ interkulturne studije}

Centar za komparativnohistorijske i interkulturne studije Filozofskog fakulteta Sveučilišta u Zagrebu, kako je već i naznačeno, preuzet će vodeću ulogu u kreiranju i organizaciji aktivnosti koje će se događati u Kuli Stojana Jankovića. Planirane aktivnosti pri tome protežu se od izvođenja znanstvenog i stručnog istraživačkog rada, organizacije terenske nastave na sve tri razine (preddiplomska, diplomska i poslijediplomska), edukacijsko-medijskoj promociji rezultata istraživanja, ali i destinacije Kule kao osobitog (interkulturnog) mjesta.

Kako bi se sve navedeno na kvalitetan način moglo omogućiti potrebno je osigurati međunarodno relevantan i kvalitetan znanstveno-stručni odbor koji će planirati, provoditi i nadgledati aktivnosti MSC i budućeg muzeja, odnosno ključnog elementa koji to može osigurati - Centra za komparativnohistorijske i interkulturne studije Filozofskog fakulteta Sveučilišta u Zagrebu. Dotično savjetodavno/upravljačko tijelo Centra stoga nesumnjivo mora biti formirano kao učinkoviti (ne preveliki) interdisciplinarni tim međunarodno priznatih profesionalaca iz određenih relevantnih područja. Iz perspektive muzeologije/baštinskih studija, koji - smatramo - svakako trebaju u tome biti uključeni, u ovom je trenutku moguće spomenuti izravnu zainteresiranost prof. Amareswara Galle (prestižnog međunarodnog stručnjaka za ekomuzeje, kulturnu raznolikost i održivi razvoj) da bude dio znanstvenog savjetodavnog odbora Centra te uvažavajući važnost praktične primjenjivosti znanstvenih spoznaja u društveno relevantnim projektima kolege iz Škotske, Michaela Hamisha Glena (ponajvećeg stručnjaka u području interpretacije baštine na europskom kontinentu). $U$ duhu izražene mediteranske poveznice mogući poželjni dodatni kandidat za odbor Centra mogao bi biti prof. Sergio Lira sa Sveučilišta u Portu (Portugal), a za interkulturnu problematiku povezanu s upotrebom baštine to bi mogao biti dr. sc. Carsten Paludan-Müller s norveškog Instituta za istraživanje kulturne baštine, dok bi za baštinski turizam relevantni savjetnik mogao biti Brice Duthion, član znanstvenog savjeta francuskog Instituta za turizam iz Pariza i suradnika nedavno otvorenog i vrlo utjecajnog Muzeja europskih civilizacija i Mediterana iz Marseillea. Centar bi time, po našem mišljenju, uključivanjem dijela navedenih stručnjaka doista mogao istovremeno ostvariti oba svoja osnovna cilja: da postane relevantni sveučilišni centar za istraživanje i praktičnu primjenu znanja u području interkulturalizma te istovremeno pokretač razvoja aktivnosti u Kuli Stojana Jankovića i time ključni regenerator razvoja zapostavljene regije (gornjih) Ravnih kotara, prostora koji ima iznimne potencijale posebice u kontekstu upotrebe baštine i razvoja na baštini utemeljenog turizma. 


\section{Komentar}

\section{Marina Jurjević}

U razdoblju od 25. svibnja do 1. lipnja 2014. godine, u sklopu projekta Kula Jankovića: spomenik kulture, pokretač održivog razvoja Ravnih kotara, u Ravnim kotarima održala se Radionica o tradicijskoj kulturi Ravnih kotara. U sklopu nje održano je nekoliko tematskih radionica pa tako i Radionica o interkulturnom i transkulturnom "dekodiranju" $i$ identifikaciji revitalizacijskih potencijala i to 30. i 31. svibnja 2014. godine u Kuli Stojana Jankovića u Islamu Grčkom. Upravo na toj radionici dr. sc. Ivan Basić s Odsjeka za povijest Filozofskog fakulteta Sveučilišta u Splitu održao je izlaganje pod naslovom Kula Janković Stojana: istraživački pristupi i neke determinante u formiranju projektnih potencijala.

U uvodnom dijelu izlaganja autor je naglasio povoljan geografski položaj i smještaj u blizini velikih obradivih površina naselja Islama Grčkog i Latinskog koji su uvjetovali kontinuitet naseljenosti od najranijih povijesnih razdoblja do danas. Odlučujuću ulogu u formiranju naselja imala su turbulentna događanja u ovom dijelu Dalmacije tijekom srednjeg vijeka kao i smještaj uz važnu srednjovjekovnu komunikaciju Via Magna koja je povezivala gradove Nin i Knin. Na temelju povijesnih izvora autor je iznio podatke o imenu, granicama i razvoju Islama Grčkog tijekom navedenog razdoblja. Također, analizirajući povijesnu građu i toponime u razdoblju od 13. do 19. stoljeća autor uspješno rekonstruira vlasničke odnose nad zemljištem i objektom od vremena posjeda ninskog biskupa do suvremenog doba.

Kula Stojana Jankovića danas predstavlja sklop gospodarskih, rezidencijalnih i fortifikacijskih objekata koji se prostiru na površini od $4500 \mathrm{~m}^{2}$. Nedjeljivi dio objekta je crkva sv. Đurđa (sv. Jurja), danas u funkciji mauzoleja obitelji Desnica. Rezimirajući rezultate arhitektonskog razvoja sklopa tijekom 18. i 19. stoljeća te tridesetih godina 20. stoljeća autor zaključuje da je riječ o "objektu izrazite arhitektonske, ali i kulturne slojevitosti čije potencijale treba iskoristiti”. Jedan od vidova daljnje revitalizacije objekta autor vidi kroz formiranje Međunarodnog sveučilišnog centra "Kula Jankovića" koji će, uz daljnje radove na obnovi, zasigurno uroditi brojnim znanstveno-istraživačkim projektima koji bi trebali rasvijetliti nepoznanice vezane kako uz razvoj same Kule tako i cijelog područja naselja Islama Grčkog i Latinskog od najranijih vremena do danas.

Uz formiranje Međunarodnog sveučilišnog centra za čije je potrebe ugovorom između vlasnika Kule, obitelji Desnica, i Sveučilišta u Zagrebu osiguran prostor od $700 \mathrm{~m}^{2}$ na razdoblje od 30 godina (2011. - 2041.), nužno je izraditi "strateški plan mobilizacije potencijala" Kule koji je preduvjet za nastavak istraživanja i obnove cijelog kompleksa, ali i "pronalaženje realnog (financijskog i inog) značaja za širu okolicu i poduzetnike tog kraja" kako navodi autor. Provođenjem navedenih mjera stvorili bi se preduvjeti na temelju kojih bi projekti vezani uz daljnju obnovu i istraživanje Kule bili konkurentni kako za daljnje sufinanciranje od strane Ministarstva kulture Republike Hrvatske, tako i za apliciranje na različite fondove Europske unije, različite sponzore ili druge izvore. Uz navedene projekte, koji bi trebali pridonijeti revitalizaciji objekta, autor navodi i niz mjera kojima bi se pospješila prepoznatljivost i dostupnost Kule široj zajednici, poput tiskanja promotivnih materijala, prevođenje postojeće literature o Kuli na strane jezike, izrade internetske stranice i dr. 
Smatram da je usporedno s daljnjim radovima na obnovi i sanaciji te znanstvenom vrednovanju istraživačkih projekata vezanih uz sklop Kule Stojana Jankovića kao i provođenja niza mjera koje predlaže dr. sc. Ivan Basić, potrebno stvoriti i određene preduvjete koji bi pridonijeli prepoznatliivosti Kule kao vrijedne kulturne baštine, ne samo na lokalnoj, već i na nacionalnoj i međunarodnoj razini. Osnovne prednosti sklopa, poput zaštite na nacionalnoj razini (nalazi se na Listi zaštićene kulturne baštine Republike Hrvatske pri Ministarstvu kulture pod brojem Z-280), blizina važnih cestovnih pravaca u Zadarskoj županiji (državna cesta D8 Zadar - Maslenica i autoceste A1 Zagreb - Split) i turističkih odredišta (Posedarje, Novigrad, Maslenica, Zadar) do današnjeg dana nisu dovoljno iskorištene. Također, u posljednjih nekoliko godina, nakon povrata dijela građe, u Kuli je ponovno izložen etnografski postav i dio umjetničke zbirke unutar koje se ističu slike Ecce Homo (17./18. stoljeće), Veduta Castellammare (19. stoljeće) i Veduta Cave (19. stoljeće) nepoznatih autora koje se nalaze pod zaštitom Ministarstva kulture Republike Hrvatske pod brojem P-4389. $S$ druge pak strane brojne aktivnosti koje su se posljednje desetljeće odvijale unutar Kule, poput kulturno-znanstvenog skupa Desničini susreti, Ljetne škole i dr. prvenstveno su bile orijentirane na malobrojne kulturne i znanstvene krugove, različite nevladine organizacije i grupe studenata koje su uglavnom bile izravno uključene u različite projekte vezane uz Kulu, bez značajnije uključenosti lokalnih zajednica, kako administrativnog središta Grada Benkovca tako i susjednih Općina Posedarje i Novigrad kojima Islam Grčki gravitira.

Slijedom navedenog, smatram da je u skoroj budućnosti potrebno uložiti dodatne napore koji bi za cilj trebali imati prepoznavanje lokaliteta u lokalnim okvirima kroz organiziranje različitih događaja u koje je potrebno uključiti širu lokalnu zajednicu kroz npr. organiziranje ekosajma, dana otvorenih vrata u sklopu kojih bi Kulu organizirano posjećivali učenici osnovnih i srednjih škola iz Zadarske županije te drugih manifestacija. Također, radi uključivanja Kule u turističku ponudu potrebna je suradnja s lokalnim turističkim zajednicama, a kao jedan od osnovnih preduvjeta je postavljanje smeđe signalizacije i tiskanje promotivnog materijala o Kuli na nekoliko stranih jezika. Osim navedenog, u svrhu turističke valorizacije potreban je angažman stručne osobe koja bi u točno precizirano radno vrijeme bila na raspolaganju posjetiteljima, ako ne tijekom cijele godine, barem u ljetnim mjesecima. Uz navedeno, sve aktivnosti vezane uz Kulu koje su danas dostupne na službenoj internetskoj stranici ${ }^{2}$ trebale bi biti sastavni dio lokalnih turističkih zajednica (TZ Grada Benkovca, TZ Općine Posedarje, TZ Općine Novigrad i TZ Zadarske županije) is cjelokupnim sadržajem dostupne barem na jednom svjetskom jeziku.

\section{es}

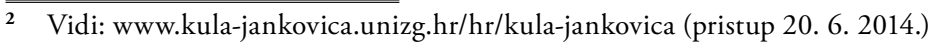




\section{Komentar Marijeta Rajković Iveta}

Sudjelujući u nekoliko znanstvenih projekata povezanih s obnovom Kule Stojana Jankovića unazad desetak godina, prateći događanja u vezi arhitektonske obnove Kule, razgovarajući o svakodnevnom životu sa stanovnicima okolnih naselja te dobivajući saznanja o polaganom, ali ipak vidljivom, povratku stanovništva u Islam Grčki i Kašić te znajući koliko je velik napor uložen za svaki mali pomak, vesele me vidljivi rezultati iako se često čini da idu jako sporim tempom.

Kroz studiju i izlaganje Ivana Basića koje je održano u okviru Radionice o interkulturnom $i$ transkulturnom "dekodiranju” $i$ identifikaciji revitalizacijskih potencijala 30. svibnja 2014. godine u Kuli Stojana Jankovića u Islamu Grčkom u okviru projekta Kula Jankovića: spomenik kulture, pokretač održivog razvoja Ravnih kotara dobili smo, između ostaloga, vrlo lijep i koncizan povijesni i arhitektonski pregled o Kuli, njenoj važnosti kao "turističkoj atrakciji" i "baštinskom potencijalu", pregled dosadašnjih istraživanja te smjernice za buduća istraživanja i njenu dugoročnu komercijalnu iskoristivost. Smatram da su svi prijedlozi kolege Basića iznimno korisni. Ovom prilikom nadopunit ću neke njegove prijedloge te navesti još prijedloga za koje se nadam da će pridonijeti što boljoj prepoznatljivosti ovoga kompleksa zaštićene kulturne baštine Republike Hrvatske te održivom razvoju šireg područja Ravnih kotara.

1. Unatoč tome što se Kula nalazi u blizini turističkih odrednica (Zadar, Posedarje, Novigrad) i blizu važnih prometnica (autoceste A1 Zagreb - Split, državna cesta D8 Zadar Maslenica) nigdje na njima nema putokaza za Islam Grčki ni za Kulu Stojana Jankovića. $\mathrm{Ni}$ u jednom turističkom uredu na području Ravnih kotara koji sam posjetila i kontaktirala, turističkoj agenciji, kao ni u njihovim podružnicama u brojnim zadarskim hotelima Kula Stojana Jankovića ne preporučuje se niti spominje posjetiteljima i turistima.

2. Razgovarajući sa stanovnicima okolnih naselja tijekom provođenja etnoloških terenskih istraživanja (rezultati su objavljeni u zborniku radova Zapisi iz gornjih Ravnih kotara. Etnološki, povijesni i muzeološki prilozi o Islamu Latinskom, Islamu Grčkom, Kašiću i Podgradini 2010. godine (ur. M. Černelić i M. Rajković Iveta). Zagreb: Sveučilište u Zagrebu, Filozofski fakultet, Odsjek za etnologiju i kulturnu antropologiju, Centar za komparativno historijske i interkulturalne studije, FF press, Zagreb) te kontaktirajući neke od njih tijekom boravka na etnološkoj Radionici o tradicijskoj kulturi Ravnih kotara od 25. svibnja do 1. lipnja 2014. godine saznala sam da većina mojih sugovornika nije bila u Kuli. Znaju da se Kula obnavlja, zanima ih što će u njoj biti i željeli bi vidjeti njenu unutrašnjost, no budući da rijetko prolaze kroz Islam Grčki (neki ga zbog ratnih trauma i namjerno zaobilaze) i da je Kula uglavnom zatvorena, nisu je posjetili. Također su objašnjavali da je Kula privatan posjed i da ne mogu "samo tako doći i tražiti da je razgledaju, niti znaju može li se to".

Kontaktirala sam i pozvala vjeroučiteljicu i učiteljice iz Osnovne škole Islam Latinski, Posedarje, Slivnica Donja da dođu na ovogodišnju spomenutu etnološku radionicu i razgledaju Kulu. Šest učiteljica s pedesetak djece osnovnoškolskog uzrasta vrlo rado se odazvalo. Djeci je Kula bila iznimno zanimljiva, posebice priče o povijesti, razgledavanje "Tamnice", 
penjanje u toranj "Kulu" i sl. Moj je prijedlog da bi trebalo organizirati više "otvorenih vrata" Kule, barem vikendima tijekom ljetnih mjeseci te uputiti osobne pozive ravnateljima i nastavnicima osnovnih i srednjih škola, kako iz susjednih mjesta tako i čitave regije. Smatram da bi na taj način djeci bila pristupačnija "zavičajna" povijest, a arboretum zanimljiva dopuna "školi u prirodi". Nadalje, djeca bi roditeljima i drugim odraslima pričala o posjetu Kuli te na taj način probudila znatiželju da je i oni posjete.

3. U Kulu bi češće trebalo pozvati vlasnike/predstavnike obližnjih OPG-ova da prezentiraju i prodaju svoje proizvode. Mišljenja sam da bi se dio posjetitelja nakon obilaska Kule uputio na obližnja obiteljska poljoprivredna gospodarstva i obiteljska poljoprivredna domaćinstva kada bi reklamni letci o njihovim djelatnostima i proizvodima bili dostupni posjetiteljima Kule. Također bi na tim gospodarstvima i domaćinstvima, kao i drugim turističkim objektima Ravnih kotara trebalo ostaviti promidžbeni materijal o Kuli Stojana Jankovića s istim ciljem. Bilo bi dobro potaknuti lokalno stanovništvo da proizvodi ekološke i etnološke suvenire koji bi se mogli kupiti u Kuli, a na taj način bi se pridonijelo samozapošljavanju i ekonomskom razvoju ovoga kraja. Umrežavanjem resursa, $s$ jedne strane Kule, $s$ druge strane OPG-ova i turističkih ustanova i djelatnika postupno bi se "mobilizirali lokalni potencijali i ostvarivao dobrobit mikroregije".

4. Trebalo bi zaposliti jednu osobu koja bi barem tijekom ljetnih mjeseci radila u Kuli, koordinirala njeno održavanje (košnju trave i sl.), vodila posjetitelje kroz postavljene muzejske zbirke i samu Kulu, osmišljavala i koordinirala razna događanja u Kuli, prodavala suvenire isl.

Nažalost, svjesni smo velike nezaposlenosti u Republici Hrvatskoj pa vjerujem da bismo pronašli mladu osobu kojoj bi se, možda uz neki program državne potpore, omogućilo stažiranje i polaganje stručnog ispita za kustosa.

5. Iako posljednja stavka, smatram je vrlo bitnom, a odnosi se na strateški plan razvoja Međusveučilišnog centra kao važnog dijela održivog razvoja Kule. Smatram da bi se uz građevinsku obnovu rezidencijalnog dijela Kule, trebalo početi raditi i na građevinskoj obnovi dijela kompleksa Kule koji je predviđen za Centar. Osiguravanjem smještajnih kapaciteta za studente, nastavnike i istraživače u Kuli i na području Ravnih kotara terenska nastava (arheološka, povijesna, etnološka i sl.), ljetne škole, seminari, festivali i ostala događanja mogli bi se održavati većim dijelom godine. U događanja bi valjalo uključiti studente preddiplomskih, diplomskih i poslijediplomskih studija ne samo iz Zagreba i Hrvatske, već za početak i iz država bivše Jugoslavije te ostalih susjednih država. Ova praksa već se provodila, no smatram da bi je osiguranje smještajnih kapaciteta uvelike intenziviralo. $U$ dosadašnjim istraživanjima premalo su bili uključeni studenti i istraživači sa Sveučilišta u Zadru te preporučujem da se s obzirom na nedostatak smještajnih kapaciteta u bližoj budućnosti treba više poraditi na uključivanju suradnika s terena.

Paralelan rad na svim navedenim prijedlozima, a koji su u sprezi sa prijedlozima kolege Ivana Basića, iziskuje minimalne financijske uloge; naglasak je prije svega na ljudskom angažmanu. Svaki je prijedlog nužan fragment koji bi podizao prepoznatljivost Kule kao kulturnog, znanstvenog i turističkog središta kako na lokalnoj, regionalnoj, nacionalnoj tako i međunarodnoj razini te doprinio kako njenom održivom razvoju, tako i razvoju šire regije zadarskog zaleđa. 